\title{
POTENSI PENGEMBANGAN TERNAK SAPI POTONG DI KECAMATAN KATINGAN TENGAH KABUPATEN KATINGAN, KALIMANTAN TENGAH
}

\author{
(Development Potential Of Beef Cattle At Central Katingan Sub-District, Katingan District \\ Central Kalimantan)
}

\author{
Jambie $^{1}$, Asro' Laelani Indrayanti ${ }^{2}$, Teguh Pribadi $^{2}$, Nurul Hidayati \\ ${ }^{1}$ Unit Pelaksana Teknis Daerah (UPTD) Pertanian Kecamatan Katingan Tengah, \\ Kabupaten Katingan, Kalimantan Tengah. \\ ${ }^{2}$ Program Studi Agribisnis, Fakultas Pertanian Universitas PGRI Palangkaraya
}

\begin{abstract}
Cattles are big ruminant livestock most widely farmed and have prospective livestock to be developed in Indonesia. This study was conducted to describe characteristics of beef cattle farmer, to predict potential development cattle agribusiness, and to determine centre of development cattle agribusiness in central Katingan sub-district. Characteristics of beef cattle farmer were analyzed by decriptive statistics. Potential development cattle business was measured by Capacity of additional ruminant population (CARP). Potential villages as centre of development cattle agribusiness was determined by location quotient (LQ) analysis. The result concludes that beef cattle farmers at central Katingan sub-district had experienced, productive age, fair labor force at the family, and most well educated. Beef cattle Agribusiness had done semiintensive at central Katingan sub-distric. The number of livestock can be added about 407.34 livestock unit/LU (equivalent to 234.64 LU of beef cattle) at central Katingan. Potential beef cattle Agribusiness basis at central Katingan sub-district i.e. Petak Puti, Tewang Panjang, and Telok where their LQ (effective CARP) values were 10.86 (38.76); 6.36 (70.33); and 1.24 (126.02), respectively. An optimally utilization of land resources management and crop-livestock systems development were applied to increase the number of beef cattle agribusiness.
\end{abstract}

Key words: Beef cattle farmer characteristics, CARP, Central Katingan subdistrict, LQ analysis, Regional development.

\section{PENDAHULUAN}

Kebutuhan daging sapi terus meningkat seiring dengan makin baiknya kesadaran masyarakat akan pentingnya gizi yang seimbang, pertambahan penduduk, dan peningkatan daya beli masyarakat. Setiap tahun Indonesia membutuhkan daging sapi antara 350.000-500.00 ton daging sapi. Konsumsi daging sapi meningkat dari 378.930 ton pada tahun 2005 menjadi 495.550 ton di tahun 2010 atau sekitar 434,86 ton per tahun dengan purata konsumsi daging sapi masyarakat $1,90 \mathrm{~kg}$ per kapita per tahun dalam lima tahun terakhir. Namun, purata populasi sapi selama lima tahun terakhir hanya 12.867.970 ekor sapi. Padahal untuk memenuhi kebutuhan daging sapi ini diperlukan populasi sapi ideal purata 14.544.280 ekor sapi per tahun selama rentang waktu tersebut. Sehingga populasi sapi yang ada hanya mampu memasok kebutuhan konsumsi daging sapi masyarakat sekitar 70\%95\% (Maluyu et al. 2010). Sisa kekurangan pasokan daging sapi dipenuhi melalui impor sapi, terutama dari Australia dan Selandia 
Baru (Priyanto, 2011). Padahal potensi sumberdaya lahan Indonesia sangat besar, jika $50 \%$ lahan tersebut dimanfaatkan saja maka potensi ternak sapi yang dapat ditampung mencapai 29 juta satuan ternak (ST), terutama daerah di luar Pulau Jawa.

Prioritas pembangunan peternakan di masa akan datang cenderung diutamakan di daerah luar Jawa. Pertimbangan utamanya adalah potensi sumberdaya lahan yang sangat luas dan kepadatan penduduk yang cenderung rendah. Potensi lahan pertanian di luar Pulau Jawa yang belum dimanfaatkan mencapai 32 juta hektar, lahan terlantar sekitar 11,50 juta hektar, dan lahan pekarangan mencapai 5,40 juta hektar. Potensi ini belum memasukkan peluang pemanfaatan lahan rawa atau lebak dan gambut yang masih belum digarap secara optimal (Maluyu et al. 2010).

Kabupaten Katingan memiliki potensi besar untuk dikembangkan sebagai pusat produksi sapi di Propinsi Kalimantan Tengah khususnya dan Indonesia pada umumnya. Kabupaten Katingan dengan luasan hampir $17.000 \mathrm{~km}^{2}$ dan didominansi oleh hutan, rawa, dan lahan terbuka. Di samping itu, di beberapa wilayah di Kabupaten Katingan, terutama di sekitar aliran Sungai Katingan, masyarakat lokal telah lama memelihara sapi lokal. Sapi ini dikenal dengan nama sapi katingan atau sapi helu. Sapi katingan merupakan plasma nutfah sapi lokal yang memiliki potensi untuk dirakit menjadi galur sapi lokal unggul karena kekhasan dan kemampuannya beradaptasi dengan kondisi tanah masam (Utomo, 2011; Prabowo 2012). Sedangkan, salah satu wilayah yang memiliki potensi besar untuk dijadikan pusat pengembangan peternakan sapi potong di Kabupaten Katingan adalah Kecamatan Katingan Tengah (Utomo, 2011).

Penelitian ini bertujuan untuk menaksir potensi pengembangan ternak sapi di Kecamatan Katingan Tengah, dengan tujuan khusus untuk mendeskripsikan ciri petani ternak sapi di Kecamatan Katingan Tengah, menaksir potensi pengembangan ternak sapi potong; dan menetapkan pusat pengembangan ternak sapi potong di Kecamatan Katingan Tengah.

\section{METODE PENELITIAN}

\section{Lokasi penelitian.}

Penelitian ini dilaksanakan di Kecamatan Katingan Tengah, Kabupaten Katingan. Penelitian ini dilakukan selama lima bulan dimulai pada Bulan Maret hingga Juli 2012.

\section{Desain Penelitian \& Percontohan.}

Penelitian ini merupakan penelitian deskriptif dengan menggunakan metode sigi pada peternakan sapi potong di Kecamatan Katingan Tengah. Populasi diambil yaitu seluruh peternak sapi potong di Kecamatan Katingan Tengah yang berjumlah 210 rumah tangga peternak (RTP). Pengambilan contoh secara sengaja berdasarkan desa-desa yang memiliki memiliki populasi sapi potong terbanyak (Hermansyah, 2006). Jumlah responden yang dicuplik adalah 21 RTP dari lima desa dengan populasi ternak sapi tertinggi. Responden RTP terbanyak berada di Desa Tumbang Lahang sebanyak 11 RTP, kemudian disusul Desa Petak Puti dan Desa Samba Danum masing-masing sebanyak tiga responden. Sedangkan untuk Desa Telok dan Desa Tewang Panjang masing-masing sebanyak dua responden.

\section{Data dan Instrumentasi.}

Data penelitian terdiri dari data primer dan data sekunder. Data primer diperoleh dari pengamatan langsung di lokasi penelitian dan informasi dari responden dengan menggunakan kuesioner. Data primer yang dikumpulkan meliputi data ciri-ciri budidaya ternak sapi rakyat di Kecamatan Katingan Tengah. Pengumpulan data tersebut diperoleh dengan menggunakan kuesioner yang dikembangkan oleh Hermansyah (2006) dan telah dimodifikasi. Data sekunder merupakan data pelengkap yang diperoleh dari instansiinstansi teknis berupa data pelaporan terkait 
dengan kegiatan peternakan dan rujukanrujukan ilmiah yang menunjang penelitian ini.

\section{Analisis data.}

Karakteristik peternak dan budidaya usaha ternak sapi dianalisis dengan menggunakan metode statistika deskriptif. Potensi pengembangan usaha ternak sapi dihitung berdasarkan analisis kapasitas penambahan ternak ruminansia (KPPTR). Persamaan yang digunakan dalam analisis ini adalah sebagai berikut (Arfa'i et al. 2009):

a. Potensi maksimum populasi ternak berdasarkan sumberdaya lahan (PMSL)

$$
P M S L=a \cdot L G+b \cdot P R+c \cdot R
$$

\section{Keterangan :}

\begin{tabular}{|c|c|}
\hline$P M S L$ & $\begin{array}{lr}\text { : potensi } & \text { maksimum } \\
\text { berdasarkan } & \text { sumberdaya }\end{array}$ \\
\hline & lahan (satuan ternak/ST) \\
\hline$a$ & $\begin{array}{l}\text { koefisien kapasitas tampung } \\
\text { lahan garapan }(1,6 \mathrm{ST} / \mathrm{Ha})\end{array}$ \\
\hline$L G$ & $\begin{array}{l}\text { luas lahan garapan tanaman } \\
\text { pangan }(\mathrm{Ha})\end{array}$ \\
\hline$b$ & $\begin{array}{l}\text { koefisien kapasitas } \\
\text { tampung padang rumput } \\
(0,5 \mathrm{ST} / \mathrm{Ha})\end{array}$ \\
\hline$P R$ & $\begin{array}{l}\text { : luas padang rumput alami } \\
\text { (Ha) }\end{array}$ \\
\hline$c$ & $\begin{array}{l}\text { koefisien kapasitas } \\
\text { tampung lahan rawa }(1,2 \\
\text { ST/Ha) }\end{array}$ \\
\hline$R$ & luas lahan rawa $(\mathrm{Ha})$ \\
\hline
\end{tabular}

b. Potensi maksimum populasi ternak berdasarkan kepala keluarga petani (PMKK)

$$
P M K K=d . K K
$$

Keterangan :

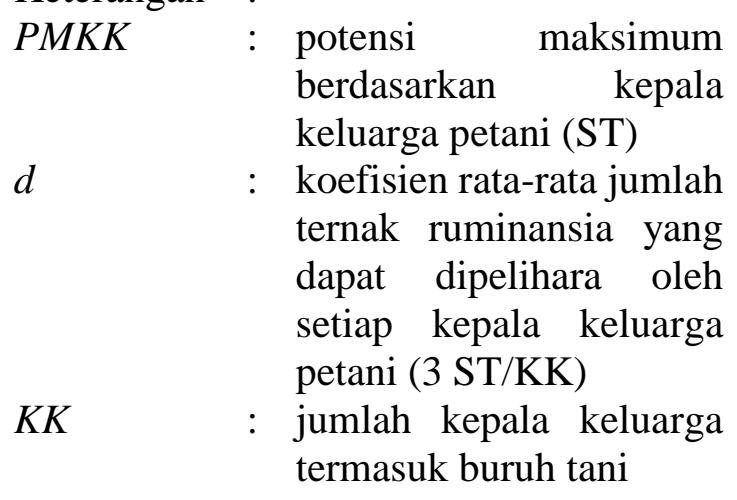

c. Kapasitas penambahan populasi ternak ruminansia berdasarkan sumberdaya lahan atau KPPTR(SL)

$$
\operatorname{KPPTR}(S L)=P M S L-P O P R I L
$$

Keterangan :

$\operatorname{KPPTR}(S L)$ : kapasitas peningkatan populasi ternak ruminansia berdasarkan sumberdaya lahan (ST)

POPRIL : populasi nyata ternak ruminansia pada tahun tertentu (ST)

d. Kapasitas penambahan populasi ternak ruminansia berdasarkan kepala keluarga petani atau KPPTR(KK)

$$
K P P T R(K K)=P M K K-P O P R I L
$$

Keterangan :

$\operatorname{KPPTR}(K K)$ : kapasitas peningkatan

populasi ternak ruminansia berdasarkan kepala keluarga petani (ST)

POPRIL : populasi nyata ternak ruminansia pada tahun tertentu (ST)

e. KPPTR efektif ditentukan dengan melihat kendala yang paling besar hal ini ditandai dengan nilai KPPTR(SL) atau $\mathrm{KPPTR}(\mathrm{KK})$ yang memiliki nilai paling kecil.
1) $\mathrm{KPPTR}(\mathrm{SL})$ efektif jika dan hanya jika KPPTR(SL) < KPPTR(KK)
2) $\operatorname{KPPTR}(\mathrm{KK})$ efektif jika dan hanya jika KPPTR(KK) < KPPTR(SL)

f. Kapasitas penambahan ternak sapi

Penambahan ternak sapi

$$
=\frac{\text { Populasi ternak sapi }}{\text { POPRIL }} \times \operatorname{KPPTR}(\text { efektif })
$$

Keterangan :

$\operatorname{KPPTR}$ (efektif) : kapasitas peningkatan populasi ternak ruminansia efektif (ST)

POPRIL : populasi nyata ternak ruminansia pada tahun tertentu (ST). 
Location quotient (LQ) adalah suatu indeks yang mengukur over specialization atau under specialization dari sektor tertentu dalam suatu daerah. LQ mengukur tingkat spesialisasi nisbi suatu daerah di dalam aktivitas sektor perekonomian tertentu. Konsep nisbi dapat diartikan sebagai tingkat spesialisasi yang membandingkan suatu daerah dengan wilayah yang lebih besar di mana daerah yang diamati merupakan bagian dari wilayah tersebut (Budiharsono, 2001 yang dikutip oleh Hardyastuti, 2008). Daerah sentra produksi ternak merupakan daerah dengan nilai LQ > 1. Persamaan LQ yang digunakan adalah:

Keterangan :

$$
L Q=\frac{S_{i}}{N_{i}}
$$

LQ : location quotient
$S_{i} \quad:$ nisbah antara populasi ternak sapi (ST) di wilayah tertentu dengan jumlah penduduk di wilayah yang sama.

$N_{i} \quad$ : nisbah antara populasi ternak sapi di kecamatan dengan jumlah penduduk di kecamatan yang sama (Arfa'i et al. 2009).

\section{HASIL DAN PEMBAHASAN}

Ciri-ciri peternak sapi di Kecamatan Katingan Tengah. Ciri-ciri yang diamati dalam penelitian ini adalah umur, tingkat pendidikan baik formal maupun nonformal, tanggungan keluarga, mata pencaharian utama, pengalaman beternak, serta jumlah ternak sapi, dan luas lahan garapan.

Tabel 1. Perimbangan ciri-ciri responden penelitian.

\begin{tabular}{|c|c|c|c|c|c|c|c|}
\hline & \multirow{3}{*}{ Uraian } & \multicolumn{6}{|c|}{ Persentase $(\%)$} \\
\hline & & \multicolumn{5}{|c|}{ Desa } & \multirow{2}{*}{$\begin{array}{c}\text { Kec. } \\
\text { KT }\end{array}$} \\
\hline & & $\mathrm{TL}$ & $\mathrm{PP}$ & $\mathrm{SD}$ & $\mathrm{TE}$ & $\mathrm{TP}$ & \\
\hline \multicolumn{8}{|c|}{ 1. Kelompok Umur (tahun) } \\
\hline & $-15-60$ & 36,36 & 66,67 & 66,67 & 100 & 50,00 & 52,38 \\
\hline & $->60$ & 63.64 & 33.33 & 33.33 & 0 & 50.00 & 47.62 \\
\hline \multicolumn{8}{|c|}{ 2. Pendidikan formal } \\
\hline & $-\mathrm{SD}$ & 0.00 & 0.00 & 33.33 & 50.00 & 0.00 & 9.52 \\
\hline & - SLTP & 72.73 & 0.00 & 33.33 & 50.00 & 0.00 & 47.62 \\
\hline & - SLTA & 27.27 & 66.67 & 33.33 & 0.00 & 50.00 & 33.33 \\
\hline & - Pendidikan Tinggi & 0.00 & 33.33 & 0.00 & 0.00 & 50.00 & 9.52 \\
\hline \multicolumn{8}{|c|}{ 3. Jumlah tanggungan keluarga (orang) } \\
\hline & $-0-3$ & 81.82 & 66.67 & 33.33 & 50.00 & 50.00 & 66.67 \\
\hline & $-4-7$ & 18.18 & 33.33 & 66.67 & 50.00 & 50.00 & 33.33 \\
\hline \multicolumn{8}{|c|}{ 4. Mata pencaharian utama } \\
\hline & - PNS & 0.00 & 66.67 & 33.33 & 0.00 & 50.00 & 19.05 \\
\hline & - Pensiunan & 0.00 & 0.00 & 0.00 & 0.00 & 50.00 & 4.76 \\
\hline & - Pedagang & 0.00 & 0.00 & 33.33 & 0.00 & 0.00 & 4.76 \\
\hline & - Petani & 100.00 & 33.33 & 33.33 & 100.00 & 0.00 & 71.43 \\
\hline \multicolumn{8}{|c|}{ 5. Pengalaman beternak (tahun) } \\
\hline & $-<5$ & 0.00 & 0.00 & 0.00 & 0.00 & 0.00 & 0.00 \\
\hline & $-5-10$ & 27.27 & 33.33 & 66.67 & 50.00 & 0.00 & 33.33 \\
\hline & $-\quad 11-15$ & 36.36 & 33.33 & 0.00 & 0.00 & 0.00 & 23.81 \\
\hline & $->15$ & 36.36 & 33.33 & 33.33 & 50.00 & 100.00 & 42.86 \\
\hline
\end{tabular}

Keterangan: Kec (Kecamatan), TL (Tumbang Lahang), PP (Petak Puti), SD (Samba Danum), TE (Telok), TP (Tewang Panjang), KT (Katingan Tengah). 
Kedelapan ciri-ciri tersebut merupakan faktor-faktor dan potensi untuk peningkatan dan pengembangan usaha peternakan sapi di Kecamatan Katingan Tengah di masa akan datang. Peternak sapi di Kecamatan Katingan Tengah merupakan kelompok penduduk produktif (Tabel 1). Lebih dari separuh responden berumur $15-60$ tahun. Perkecualiaan responden peternak di Desa Tumbang Lahang yang didominasi oleh peternak berusia lanjut. Hal ini merupakan potensi untuk mengembangkan dan meningkatkan produktivitas ternak sapi di Kecamatan Katingan Tengah.

Produktivitas peternak berhubungan langsung dengan usia peternak. Peternak dengan usia produktif diharapkan mampu meningkatkan produktivitas agribisnis peternakan sapi. Produktivitas kerja secara rasional dipengaruhi oleh kekuatan fisik dan kemampuan daya pikir. Pada umur produktif kekuatan fisik masih baik sehingga tanggapan terhadap pengambilan tindakan dan usaha peningkatan pengetahuan dan ketrampilan dalam menerima informasi dan teknologi baru untuk menunjang usaha dan produktivitas ternak cukup baik (Mastuti dan Hidayat, 2009).

Tingkat pendidikan responden cukup baik. Sepertiga responden peternak di Kecamatan Katingan Tengah merupakan lulusan SLTA dan hampir 10\% peternak yang ada merupakan alumni perguruan tinggi (PT). Namun, mayoritas $(47,46 \%)$ tingkat pendidikan responden adalah tamatan SLTP (Tabel 1). Namun demikian, peternak di Kecamatan Katingan Tengah melakukan peningkatan pengetahuan dan keterampilan melalui pendidikan nonformal, baik pelatihan ataupun kursus tentang budidaya ternak sapi. Petani ternak sapi minimal pernah mengikuti kegiatan kursus dan pelatihan yang diadakan oleh dinas pertanian dan peternakan ataupun balai penyuluh pertanian (BPP). Pendidikan baik formal maupun nonformal berperan penting dalam tingkat adopsi teknologi peternakan (Arfa'i, 2009). Sehingga wawasan dan pengetahuan peternak dalam teknologi terbaru budidaya ternak sapi meningkat.

Jumlah tanggungan keluarga merupakan jumlah anggota rumah tangga petani (RTP) yang bisa menjadi beban keluarga jika tidak produktif tetapi juga merupakan potensi tenaga kerja untuk kegiatan agribisnis peternakan sapi. Secara umum jumlah tanggungan RTP di Kecamatan Katingan Tengah dikelompokan dalam keluarga kecil (jumlah tanggungan $<4$ orang). Kecuali di Desa Samba Danum, duapertiga responden memiliki tanggungan keluarga $>3$ orang (Tabel 1).

Mayoritas peternak sapi di Kecamatan Katingan Tengah merupakan petani. Selain bertani mereka juga melakukan kegiatan perkebunan baik tanaman hortikultura ataupun tanaman perkebunan yang lain, terutama karet. Perimbangan yang kedua, adalah pegawai negeri sipil (PNS), yaitu sebesar hampir seperlima responden. Sisanya adalah pedagang atau pensiunan PNS dan perimbangan dari gabungan keduanya tidak lebih dari 10\% (Tabel 1).

Pengalaman merupakan salah satu kunci keberhasilan dari agribisnis peternakan sapi. Pengalaman beternak semakin meningkatkan pengetahuan dan keterampilan dalam budidaya dan pengelolaan ternak sapi. Sebagian besar usaha peternakan sapi di Kecamatan Katingan Tengah merupakan kegiatan turun temurun. Hampir separuh petani ternak sapi di telah melakukan kegiatan budidaya sapi > 15 tahun dan sepertiganya telah melakukan budidaya sapi 5-10 tahun (Tabel 1).

\section{Potensi ternak sapi di Kecamatan Katingan Tengah.}

Populasi ternak sapi di Kecamatan Katingan Tengah adalah 270 ekor sapi (183,5 ST). Purata kepemilikan ternak oleh petani responden 12,86 \pm 8,61 ekor. Peternak sapi di Desa Petak Puti memiliki purata kepemilikan ternak sapi tertinggi sebanyak 21,67 $\pm 21,13$ ekor. Sedangkan kepemilikian ternak sapi terkecil adalah peternak yang berasal dari Desa 
Telok sebanyak 8,00 $\pm 0,00$ ekor (Tabel 2). Purata kepemilikan ternak pada penelitian ini lebih banyak dibandingkan dengan purata kepemilikan ternak sapi di Kecamatan Katingan Hilir yang hanya 3,16 $\pm 0,32$ ekor/RTP (Prabowo, 2012). Purata kepemilikan ternak sapi yang secara ekonomis layak dikembangkan adalah 2-34 ekor/RTP (Utomo, 2011).

Usaha ternak sapi di Kecamatan Katingan Tengah memenuhi kelayakan untuk dikembangkan menjadi usaha agribisnis ternak yang menguntungkan. Hal ini dibuktikan dengan pengelolaan ternak sapi yang lebih baik. Ternak sapi telah dipelihara secara intensif dan atau semiintensif. Pakan yang diberikan tidak hanya mengandalkan dari pasokan alamiah saja, namun juga sudah memanfaatkan hijuan makan ternak (HMT) unggulan terutama dari jenis leguminosa. Kesehatan ternak mulai diperhatikan. Sistem reproduksi ternak mulai diperbaiki. Selain itu, Indikasi-indikasi peternakan sapi semiintensif yang dilaksanakan di sana yaitu nisbah sapi anakan dengan sapi dewasa $>25 \%(32,35 \%)$ menunjukan bahwa laju pertumbuhan populasi sapi cukup baik. Nisbah sapi jantan dengan sapi betina dalam angka 1:1,52 juga merupakan indikasi bahwa budidaya ternak sapi masih dalam kategori cukup baik. Akan tetapi, belum adanya pasar hewan di Kabupaten Katingan menjadi salah satu penghambat pengembangan peternakan sapi terkait dengan pemasaran sapi. Pengelolaan ternak sapi juga meliputi penanganan hasil, pemasaran, dan pengaturan tenaga kerja (Elly et al. 2008).

Tabel 2. Purata ternak sapi (ekor) dan luasan lahan (hektar) yang dimiliki oleh responden penelitian.

\begin{tabular}{lcccccc}
\hline \multirow{2}{*}{ Peubah } & TL & PP & SD & TE & TP & \multirow{2}{*}{ Kec. } \\
\cline { 2 - 6 } & \multicolumn{7}{c}{ Pemilikan ternak } \\
Jantan dewasa & $1,64 \pm 1,03$ & $2,67 \pm 1,15$ & $2,33 \pm 1,15$ & $1,50 \pm 0,71$ & $2,50 \pm 2,12$ & $1,95 \pm 1,12$ \\
Jantan dara & $1,55 \pm 0,82$ & $2,67 \pm 2,08$ & $2,00 \pm 2,00$ & $1,50 \pm 0,71$ & $2,00 \pm 1,41$ & $1,81 \pm 1,21$ \\
Jantan pedet & $1,18 \pm 0,75$ & $3,67 \pm 5,51$ & $1,33 \pm 1,15$ & $0,00 \pm 0,00$ & $0,00 \pm 0,00$ & $1,33 \pm 2,15$ \\
Betina dewasa & $4,27 \pm 1,00$ & $4,33 \pm 2,31$ & $4,00 \pm 1,00$ & $4,00 \pm 1,41$ & $4,50 \pm 2,12$ & $4,24 \pm 1,22$ \\
Betina dara & $1,27 \pm 1,10$ & $4,00 \pm 3,61$ & $1,33 \pm 1,53$ & $1,00 \pm 1,41$ & $2,00 \pm 2,83$ & $1,71 \pm 1,90$ \\
Betina pedet & $1,36 \pm 0,81$ & $4,33 \pm 6,66$ & $2,33 \pm 3,21$ & $0,00 \pm 0,00$ & $1,50 \pm 2,12$ & $1,81 \pm 2,73$ \\
\hline Jumlah & $11,27 \pm 4,29$ & $21,67 \pm 1,13$ & $13,33 \pm 6,81$ & $8,00 \pm 0,00$ & $12,50 \pm 2,12$ & $12,86 \pm 8,61$ \\
\hline \multirow{7}{*}{ Pemilikan lahan } \\
Penggembalaan & $3,00 \pm 1,02$ & $5,67 \pm 3,79$ & $4,33 \pm 1,53$ & $2,00 \pm 0,00$ & $3,50 \pm 0,71$ & $3,52 \pm 1,84$ \\
Pertanian & $3,36 \pm 1,19$ & $3,33 \pm 0,58$ & $2,67 \pm 0,58$ & $2,50 \pm 0,71$ & $3,00 \pm 0,71$ & $3,14 \pm 1,00$ \\
\hline Jumlah & $6,36 \pm 1,31$ & $9,00 \pm 4,36$ & $7,00 \pm 2,00$ & $4,50 \pm 0,71$ & $6,50 \pm 0,71$ & $6,67 \pm 2,14$ \\
\hline
\end{tabular}

Keterangan: Simbol desa dan kecamatan merujuk pada Tabel 1. $n$ (kecamatan) $=21$. Nilai yang disajikan merupakan $\bar{x} \pm s d$

Purata luasan lahan penggembalaan dan lahan pertanian yang dimiliki oleh responden petani ternak di Kecamatan Katingan Tengah masing masing adalah 3,52 $\pm 1,84 \mathrm{Ha} / \mathrm{RTP}$ dan $3,14 \pm 1,00 \mathrm{Ha} / \mathrm{RTP}$ atau secara keseluruhan $6,67 \pm 2,14 \mathrm{Ha} / \mathrm{RTP}$ (Tabel 2). Luasan lahan yang dimiliki oleh petani ternak sapi di
Kecamatan Katingan Tengah lebih luas dibandingkan luas lahan penggembalaan yang dimiliki oleh petani ternak sapi bali di Kecamatan Katingan Hilir, yaitu sebesar tiga hektar (Prabowo, 2012). Akan tetapi, luas lahan pertanian petani di Kecamatan Katingan Tengah lebih rendah dibandingkan penelitian 
sebelumnya, yaitu 3,14 $\pm 1,00 \mathrm{Ha} / \mathrm{RTP}<5,44$ $\pm 1,15 \mathrm{Ha} / \mathrm{RTP}$.

Lahan merupakan salah satu faktor produksi dalam pengembangan ternak sapi. Usaha ternak sapi merupakan proses yang menggabungkan antara unsur-unsur produksi yang meliputi lahan, ternak, tenaga kerja, dan modal dalam rangka menghasilkan produk peternakan (Elly et al. 2008). Namun, hubungan antara lahan dan ternak bersifat dinamis. Potensi pengembangan budidaya sapi oleh peternak dapat lebih ditingkatkan melalui perbaikan teknologi dan penerapan sistem pertanian tanaman dan ternak secara terpadu (crop livestock system). Sistem pertanian ini berusaha untuk meningkatkan pemanfataan limbah usahatani tanaman untuk pakan dan pemanfaatan kotoran ternak untuk pupuk tanaman (Arfa'i, 2009).

Walaupun potensi pengembangan ke arah tersebut belum dilakukan secara optimal, namun potensi yang ada sangat menjanjikan untuk dikembangkan. Kunci pembangunan peternakan yang bagus harus memadupadankan empat peubah, yaitu: (1) peternak, yaitu pelaku utama dalam pembangunan peternakan yang harus ditingkatkan pendapatan dan kesejahteraannya; (2) ternak sapi, benda yang harus ditingkatkan produksi dan produktivitasnya; (3) lahan, faktor produksi yang digunakan sumber pakan dan lingkungan budidaya ternak sapi; dan (4) teknologi sebagai alat rekayasa untuk mencapai sasaran tersebut (Utomo, 2011).

\section{Potensi pengembangan wilayah di Kecamatan Katingan Tengah dalam budidaya ternak sapi.}

Kecamatan Katingan Tengah masih dapat ditingkatkan lagi jumlah ternak yang ada. Berdasarkan analisis KKPTR di Kecamatan Katingan Tengah masih mampu menampung ternak sebanyak 407,34 ST. Semua desa di Kecamatan Katingan Tengah masih mampu menampung ternak, kecuali
Desa Tumbang Lahang, Samba Danum, dan Samba Kahayan (Tabel 3). Ada tiga desa dengan KPPTR efektif $>100$, yaitu Samba Katung, Telok, dan Rantau Asem. Desa Samba Katung merupakan desa yang paling potensial untuk dilakukan penambahan populasi ternak sapi. Potensi sumberdaya lahannya masih mampu menampung tambahan ternak sebanyak 194,55 ST.

Seluruh nilai KPPTR efektif desa-desa di di Kecamatan Katingan Tengah dibatasi oleh keberadaan sumberdaya lahan yang belum dimanfaatkan secara optimal atau belum terisalah dengan baik. Jika potensi sumberdaya lahan yang ada dimanfaatkan secara optimal maka satuan ternak yang dapat ditambahkan akan lebih banyak dan tidak ada desa yang mengalami penjenuhan ternak. Lebih lanjut dukungan sumberdaya manusia sebagai faktor pembatas masih belum dimanfaat dengan baik. Hal ini ditandai dengan PMKK mayoritas desa di Kecamatan Katingan Tengah menunjukan bilangan ribuan (Tabel 3). Sumberdaya lahan yang merupakan faktor pembatas pengembangan ternak. Hal ini sejalan dengan penelitian dilakukan oleh Hermansyah (2006).

Lahan sangat penting dalam usaha peternakan sapi. Lahan digunakan sebagai lokasi budidaya ternak maupun sebagai penyedia pakan ternak (Sofyan, 2006). Lahanlahan usaha tani seperti sawah, kebun campuran, semak belukar, kebun kelapa sawit, perkebunan rakyat, dan belukar rawa merupakan potensi pengembangan ternak sapi (Pelitawati, 2006). Secara umum pengembangan ternak di suatu daerah memerlukan pengukuran potensi sumberdaya yang tersedia. Sumberdaya tersebut mencakup ketersediaan lahan dan pakan, tenaga kerja dan potensi ternak yang akan dikembangkan. Potensi tersebut ditentukan oleh tersedianya tanah pertanian, kesuburan tanah, iklim, topografi, ketersediaan air dan pola pertanian yang ada (Wiyatna, 2002). 
Tabel 3. Nilai KPPTR dan LQ di masing-masing desa di Kecamatan Katingan Tengah.

\begin{tabular}{|c|c|c|c|c|c|c|c|c|c|}
\hline \multirow{3}{*}{ Desa } & \multicolumn{6}{|c|}{ Potensi pengembangan ternak sapi (ST) } & \multicolumn{3}{|c|}{$\begin{array}{c}\text { Pusat pengembangan } \\
\text { ternak sapi }\end{array}$} \\
\hline & \multirow{2}{*}{ PMSL } & \multirow{2}{*}{ PMKK } & \multirow{2}{*}{$\begin{array}{l}\text { Pop. } \\
\text { Nyata }\end{array}$} & \multicolumn{3}{|c|}{ KPPTR } & \multirow{2}{*}{$\begin{array}{c}\text { Sapi } \\
\text { (ekor) }\end{array}$} & \multirow{2}{*}{$\begin{array}{l}\text { Pend. } \\
\text { (jiwa) }\end{array}$} & \multirow{2}{*}{ LQ } \\
\hline & & & & SL & KK & Efektif & & & \\
\hline Samba Katung & 256,90 & $1.955,50$ & 62,35 & 194,55 & $1.893,15$ & 194.55 & 25 & 2.490 & 0,22 \\
\hline Telok & 252,50 & $1.025,65$ & 126,48 & 126,02 & 899,17 & 126.02 & 75 & 1.306 & 1,24 \\
\hline Rantau Asem & 169,20 & $1.025,65$ & 59,63 & 109,57 & 966,02 & 109.57 & 20 & 2490 & 0,33 \\
\hline Napu Sahur & 115,50 & 369,90 & 34,70 & 80,80 & 335,20 & 80.80 & 10 & 471 & 0,46 \\
\hline Tewang Panjang & 171,80 & 181,41 & 101,47 & 70,33 & 79,94 & 70.33 & 68 & 231 & 6,36 \\
\hline Tumbang Marak & 127,90 & 599,21 & 60,74 & 67,16 & 538,47 & 67.16 & 12 & 763 & 0,34 \\
\hline Tumbang Hangei & 100,60 & 392,67 & 49,40 & 51,20 & 343,27 & 51.20 & 21 & 500 & 0,91 \\
\hline Tumbang Kalemai & 131,60 & $1.176,44$ & 84,41 & 47,19 & $1.092,03$ & 47.19 & 11 & 1.498 & 0,16 \\
\hline Samba Bakumpai & 180,46 & $1.446,60$ & 135,50 & 44,96 & $1.311,10$ & 44.96 & 63 & 1.842 & 0,74 \\
\hline Petak Puti & 142,10 & 148,43 & 103,34 & 38,76 & 45,09 & 38.76 & 95 & 189 & 10,86 \\
\hline Tumbang Pariyei & 65,40 & 301,57 & 34,45 & 30,95 & 267,12 & 30.95 & 8 & 384 & 0,45 \\
\hline Batu Badinding & 84,20 & $1.499,21$ & 64,20 & 20,00 & $1.435,01$ & 20.00 & 30 & 1.909 & 0,34 \\
\hline Mirah Kalanaman & 50,90 & $3.760,99$ & 37,02 & 13,88 & $3.723,97$ & 13.88 & 0 & 4.789 & 0,00 \\
\hline Samba Kahayan & 174,70 & $2.033,25$ & 239,33 & $-64,63$ & $1.793,92$ & -64.63 & 57 & 2.589 & 0,48 \\
\hline Samba Danum & 107,20 & $2.758,90$ & 206,09 & $-98,89$ & $2.552,81$ & -98.89 & 90 & 3.513 & 0,55 \\
\hline Tumbang Lahang & 326,70 & $1.194,50$ & 651,21 & $-324,51$ & 543,29 & -324.51 & 586 & 1.521 & 8,32 \\
\hline Total & $2.457,66$ & $19.869,90$ & $2.050,32$ & 407,34 & $17.819,58$ & 407.34 & 1.171 & 25.301 & 1,00 \\
\hline
\end{tabular}

Keterangan: KPPTR efektif merupakan nilai terendah dari dua nilai KPPTR, yaitu: KPPTR-SL atau KPPTR-KK. Tanda minus (-) berarti pengurangan ST di desa tersebut. Angka yang diberi tanda tebal menunjukan nilai KPPTR efektif (>100) dan LQ (>1).

\section{Pusat pengembangan budidaya ternak sapi di Kecamatan Katingan Tengah.}

Ada empat desa di Kecamatan Katingan Tengah yang potensial dikembangkan menjadi pusat pengembangan ternak sapi (LQ > 1), yaitu Desa Petak Puti, Desa Tumbang Lahang, Desa Tewang Panjang, dan Desa Telok dengan nilai LQ berturut-turut: 10,$86 ; 8,32 ; 6,36$; dan 1,24 (Tabel 3). Nilai LQ > 1 menunjukan bahwa kepemilikan ternak di keempat desa tersebut lebih baik dibandingkan kepemilikan ternak sapi di tingkat kecamatan. Keempat desa tersebut merupakan desa-desa dengan populasi ternak sapi yang terbanyak. Sedangkan, Desa Samba Danum dengan populasi ternak sapi terbanyak ketiga, namun memiliki LQ < 1. Ini disebabkan oleh jumlah penduduk di Desa Samba Danum cukup banyak (3.513 jiwa).

Hanya Desa Tumbang Lahang yang memiliki nilai KPPTR negatif dibandingkan desa-desa lain dengan nilai LQ $>1$. Sehingga berdasarkan dua peubah ini, maka di Kecamatan Katingan Tengah hanya ada tiga desa yang potensial dikembangkan menjadi wilayah pusat peternakan sapi, yaitu Desa Petak Puti, Desa Tewang Panjang, dan desa Telok. Desa Tumbang Lahang dapat dijadikan pusat pengembangan ternak sapi hanya jika potensi sumberdaya lahan yang ada ditingkatkan, baik melalui perluasan lahan peternakan atau penerapan sistem pertanianternak terpadu.

Desa-desa dengan nilai LQ $>1$ dan KPPTR efektif positif mengindikasikan bahwa desa-desa tersebut merupakan desa dengan potensi sumberdaya lahan yang memadai dan memiliki kecukupan persediaan hijauan pakan ternak sapi untuk memenuhi kebutuhan pakan sapi yang meningkat. Selain itu, hal ini juga menandakan bahwa tingkat kepemilikan ternak sapi potong di desa-desa tersebut lebih 
baik dibandingkan dengan kepemilikan ternak sapi di keseluruhan kecamatan (Hardyastuti, 2008).

Secara umum ada tiga faktor penting dalam pengembangan sapi potong di suatu wilayah yaitu pertimbangan teknis, sosial, dan ekonomis. Pertimbangan teknis mengarah kepada kesesuaian pada sistem produksi yang berkesinambungan, ditunjang oleh kemampuan manusia dan kondisi agroekologis. Pertimbangan sosial terdiri dari penerimaan masyarakat terhadap keberadaan ternak tanpa menimbulkan konflik sosial. Pertimbangan ekonomis mengandung arti bahwa ternak yang dipelihara harus menghasilkan nilai tambah bagi perekonomian daerah serta bagi pemeliharanya sendiri. Selanjutnya, faktor-faktor lain yang mempengaruhi perkembangan peternakan secara eksternal di antaranya: infrastruktur, keterpaduan dan koordinasi lintas sektoral, perkembangan penduduk, serta kebijakan pengembangan wilayah (Arfa'i 2009).

\section{KESIMPULAN}

Kecamatan Katingan Tengah berpotensi dikembangkan menjadi pusat pengembangan ternak sapi di akan datang. Hal ini ditandai dengan ciri-ciri petani ternak sapi yang telah berpengalaman, masih dalam usia produktif, potensi tenaga kerja dalam keluarga yang cukup, dan tingkat pendidikan yang cenderung lebih baik. Lebih lanjut, potensi masukan produksi untuk mendukung usaha ternak sapi juga cukup mendukung. Purata kepemilikan ternak dan luasan lahan masing-masing adalah $12,86 \pm 8,61$ ekor/RTP dan 6,67 $\pm 2,14$ Ha/RTP. Kecamatan Katingan Tengah masih mampu menampung ternak sebanyak 407,34 ST setara ternak sapi dewasa sebanyak 234,64 ST. Tiga desa dengan potensi terbesar untuk dilakukan penambahan ternak sapi adalah Desa Samba Katung (78,01 ST), Telok (74,73 ST), dan Tewang Panjang (47,13 ST). Pusat pengembangan ternak sapi di Kecamatan Katingan Tengah yaitu Desa Petak Puti, Tewang Panjang, dan Telok dengan nilai LQ
(KPPTR efektif) masing-masing sebesar 10,86 $(38,76) ; 6,36(70,33)$; dan 1,24 (126,02).

\section{DAFTAR PUSTAKA}

Arfa'i. 2009. Potensi dan strategi pengembangan usaha sapi potong di Kabupaten Lima Puluh Kota Sumatera Barat. [Disertasi]. SPS IPB, Bogor.

Arfa'i. W., K. Fuah, A. H. Syefuddin, A. 2009. Potensi pengembangan usaha sapi potong dalam sistem usahatani di Kabupaten Lima Puluh Kota Sumatera Barat. J Indon Trop Anim Agric 34: 5473.

Budiharsono, S. 2001. Teknis analisis pembangunan wilayah pesisir dan lautan. Pradnya Paramita, Jakarta

Elly, F. H., B. M. Sinaga, S. U. Kuntjoro, N. Kusnadi. 2008. Pengembangan usaha ternak sapi rakyat melalui integrasi sapitanaman di Sulawesi Utara. J Litbang Pertanian 27: 63-68.

Hardyastuti, D. M. 2008. Strategi pengembangan wilayah Kabupaten Grobogan sebagai sentra produksi sapi potong. [Skripsi]. Fapet IPB, Bogor

Hermansyah, B. M. 2006. Kajian pengembangan peternakan sapi potong di Kecamatan Agrabinata, Kabupaten Cianjur. [Skripsi]. Fapet IPB, Bogor.

Mastuti, S., N. N. Hidayat. 2009. Peranan tenaga kerja perempuan dalam usaha ternak sapi perah di Kabupaten Banyumas. J. Produksi Ternak 11: 40-47

Pelitawati, S. 2006. Analisis potensi sumberdaya lahan untuk arahan pengembangan sapi potong di Kabupaten Bangka. [Tesis]. SPS IPB, Bogor 
Prabowo, B. 2012. Strategi peningkatan produktivitas sapi lokal berbasis sumberdaya lokal di Kecamatan Katingan Hilir Kabupaten Katingan Kalimantan Tengah. [Tesis]. PPS Unpar, Palangkaraya.

Priyanto, D. 2011. Strategi pengembangan usaha ternak sapi potong dalam mendukung program swasembada daging sapi dan kerbau tahun 2014. $J$ Litbang Pertanian 30: 108-116.

Sofyan, A. 2006. Dukungan kebijakan perluasan areal untuk pengembangan kawasan ternak kerbau. Di dalam:
Prosiding lokakarya nasional usaha ternak kerbau mendukung program kecukupan daging sapi. Puslitbang Peternakan, Bogor.

Utomo, B. N. 2011. Keragaman fenotipik dan genetik, profil reproduksi serta strategi pelestarian dan pengembangan sapi katingan di Kalimantan Tengah. [Disertasi]. SPS IPB, Bogor.

Wiyatna, M. F. 2002. Potensi dan strategi pengembangan sapi potong di Kabupaten Sumedang Propinsi Jawa Barat. [Tesis]. SPS IPB, Bogor. 